\title{
Da lexicologia social a uma lexicologia sócio-histórica: caminhos possíveis
}

\author{
From social lexicology to socio-historical lexicology: \\ possible paths
}

\author{
César Nardelli Cambraia \\ Universidade Federal de Minas Gerais/CNPq
}

Resumo

Este artigo tem como objetivo discutir caminhos para o remodelamento da lexicologia social proposta por Georges Matoré. Na primeira parte, descrevese a abordagem de Matoré em suas linhas gerais e apresentam-se brevemente as principais críticas que recebeu. Na segunda parte, realiza-se um estudo de caso como forma de identificar caminhos para o referido remodelamento. Defende-se ao final a necessidade de estudar o léxico dentro de um quadro mais amplo de análise em prol de uma lexicologia sócio-histórica.

Palavras-chave

Lexicologia, Georges Matoré, Linguística histórica, Variação linguística.

\section{Abstract}

The aim of this paper is to discuss routes for the remodeling of the social lexicology proposed by Georges Matoré. In the first part, we describe Matoré's approach in its main lines and briefly present the main criticism it received. In the second part, we present a case study as a way of identifying routes for the remodeling of the mentioned approach. Finally, we claim for the necessity of studying lexicon within a broader frame of analysis on behalf of a sociohistorical lexicology. 


\section{Keywords}

Lexicology, Georges Matoré, Historical linguistics, Linguistic variation. 


\section{Antecedentes}

A falta de informações mais seguras sobre a primeira ocorrência da expressão lexicologia social no campo dos estudos linguísticos impede que se afirme que Georges Matoré (1908-1998) tenha sido seu criador, mas pode-se dizer seguramente que foi ele quem a colocou em evidência desde seu artigo seminal "La lexicologie sociale", publicado no periódico L'Information Littéraire em 1949.

A abordagem de estudo do léxico proposta por Matoré, que se caracteriza pela forte valorização da realidade social de uma dada comunidade, tem tido seus antecedentes situados nos estudos de Ferdinand Brunot (1860-1938): segundo Chevalier (1995, p. 258) e Candel (2006, p. 142), foi Brunot quem lançou as bases da lexicologia social. Brunot, responsável pela cadeira de História da Língua Francesa a partir de 1900 na Université de Paris-Sorbonne, tinha sido formado sob a influência de Gaston Paris e Arséne Darmsteter e publicado suas contribuições na famosa obra Histoire da la Langue Française (JULLEVILLE, 1905-2000) - caraterizava-se por uma orientação bastante particular:

a ênfase é posta na língua como um fenômeno humano e social, na filologia histórica, e tanto na história interna quanto na geografia externa da língua, além de propor os primeiros passos da lexicologia social. (CANDEL, 2006, p. 142; tradução nossa).

Para Chevalier (1995, p. 258), o lançamento dos princípios da lexicologia social teria sido uma reação de Brunot, levada a cabo a partir do tomo IV da Histoire da la Langue Française, em função de críticas que recebeu de Charles Bally em resenha da obra La Pensée et la Langue (1922) do próprio Brunot: Bally, assim como Sechehaye, reprovava-o, por deixar de lado a análise estritamente linguística, para estabelecer analogias casuais entre conceitos e meios de expressão. 


\section{A lexicologia social de Matoré}

Tem-se considerado como a obra fundamental de exposição da visão da lexicologia social de Matoré a publicação intitulada La Méthode en Lexicologie: Domaine Français, de 1953. Essa obra havia sido precedida de outras obras relevantes sobre o tema: sua tese de doutorado, defendida em 1946, sobre o vocabulário de Theóphile Gautier (1811-1872) de 1833 a 1845 (MATORÉ, 1951); dois artigos em co-autoria com Greimas (em 1948 e 1950), em que expuseram suas insatisfações com a lexicologia que se praticava na França até fins dos anos 40; e o já mencionado artigo de 1949 da revista L'Information Littéraire. Seguiram-se à referida obra fundamental outras experiências de aplicação de seu método ao vocabulário da língua francesa: da Idade Media (MATORÉ, 1985) e do séc. 16 (MATORÉ, 1988).

\subsection{As ideias fundamentais}

A lexicologia social de Matoré fundamenta-se em uma série de postulados, dos quais aqui se apresentam os que parecem ser os mais distintivos. ${ }^{1}$

Primeiramente, rejeita a ideia de distinção (possibilidade de existência independente) entre significante e significado que, segundo sua leitura, teria sido defendida por Saussure e assume que há uma indissociabilidade entre forma e conceito, pois “o pensamento só nos é conhecido por sua expressão” (p. 21). Essa indissociabilidade é argumentada retomando propostas da filosofia (MerleauPonty: "o pensamento e a expressão se constituem simultaneamente" [p. 33]) e da psicologia (Piaget: "nas crianças, a aquisição do vocabulário está relacionada com o desenvolvimento de conceitos" [p. 33]).

Parece ser central para Matoré considerar que a criação de uma palavra equivale à formação de um conceito: "no dia em que a palavra árvore aparece, nasce o conceito (...), uma ideia que estava 'no ar' se concretiza, se cristaliza sob a forma da palavra” (p. 42). Esse processo, individual na origem, é seguido de uma socialização, que faz difundir e coletivizar, por meio da palavra, o conceito formado: "uma palavra analisa e objetiviza o pensamento individual (...) e permite, assim, ao conceito ultrapassar o estágio individual e afetivo: ela racionaliza, classifica, diferencia, generaliza, abstratiza o pensamento" (p. 36-37). Esse partilhamento ocorre não apenas pela sociedade mas também através dos tempos: "é cristalizando e fixando o conceito que a palavra lhe permite ser transmitido através de gerações (...): ela é um instrumento de compreensão social" (p. 39). É interessante salientar que Matoré considera que a palavra representa uma espécie de mapeamento do mundo por parte dos falantes: 
Na realidade, as palavras não exprimem as coisas, mas a consciência que os homens têm delas. Para a lexicologia, os fatos sociais têm, com efeito, o aspecto de coisas, mas das coisas vistas, sentidas, compreendidas pelos homens; nossa disciplina deverá então visar às realidades sociológicas das quais o vocabulário é a "tradução", ao mesmo tempo objetivamente, como realidades independentes do indivíduo, e subjetivamente, em função dos seres que vivem em um meio concreto, em certas condições sociais, econômicas, estéticas, etc. (p. 42-43, itálico do original)

O caráter social da palavra está no cerne da atenção da lexicologia de Matoré: "uma palavra, seja abstrata seja concreta, tem sempre um valor social mais ou menos racional ou afetivo: é por esse aspecto da significação que se interessa a lexicologia" (p. 21). Como as palavras são consideradas "o reflexo de um estado da sociedade" (p. 43), é natural que se busque no vocabulário os meios para compreensão da sociedade:

A lexicologia tem por objeto, como a sociologia, o estudo dos fatos sociais (...). O que distingue uma ciência da outra não é apenas o seu objeto, é a diversidade formal, o ponto de vista. O da lexicologia é particular: é partindo do estudo do vocabulário que tentaremos explicar uma sociedade. Podemos também definir a lexicologia como uma disciplina sociológica utilizando o material linguístico que são as palavras (p. 49-50).

Matoré interpreta a organização do vocabulário a partir de uma concepção estruturalista, admitindo que as palavras existem na consciência em relações recíprocas (uma visão sistêmica de vocabulário): "a palavra não está isolada na consciência: ela estabelece com suas vizinhas, no contexto, relações sintagmáticas" (p. 21, itálico do original) e "independentemente do contexto, a palavra está ligada na consciência a outras palavras a que se assemelham, seja pela forma, seja pelo sentido: estas são as relações associativas" (p. 21, itálico do original). Entretanto, Matoré se afasta nitidamente do estruturalismo saussureano ao atribuir ao fator social o principal papel na organização do vocabulário. " "há uma hierarquia no léxico, mas ela é de origem sociológica, não morfológica; ela varia também segundo as épocas e os meios [sociais]" (p. 42). Decorre, portanto, dessa concepção que os estudos lexicológicos devem focar-se, segundo sua visão, no conceito das palavras (que refletem uma concepção de mundo de uma dada sociedade), e não em aspectos formais das palavras: 
A palavra (...) apresenta aspectos morfológicos, sintáticos, estilísticos, etc. [mas] a lexicologia, negligenciando essas características secundárias, realizará sobre o real um recorte permitindo-lhe isolar, para melhor estudar, a função semântica da palavra (p. 23).

Matoré afasta-se também de Saussure ao relativizar a oposição entre sincronia e diacronia: "é difícil adotar sem modificação a concepção estática de Saussure; parece impossível abstrair a palavra do fator tempo, pelo fato de ser impossível isolar um elemento das operações que o produziram" (p. 55, itálico do original). Em função disso, propõe uma atenuação da separação rígida de Saussure:

A palavra que empregamos foi pronunciada com valores diferentes pelas gerações que nos precederam. A palavra tem um passado. $A$ palavra se lembra. Acreditamos que, entre lexicologia descritiva e lexicologia histórica, há, não continuidade, mas complementariedade (p. 55, itálicos do original).

Os aspectos sintetizados acima podem ser considerados como pressupostos teóricos da lexicologia social de Matoré (embora ele não os nomeie como tal). Em função desses pressupostos, Matoré propõe um conjunto de procedimentos para realização dos estudos de lexicologia social, os quais consistem naturalmente em seu método (que é o aspecto que considerava mais importante na obra de 1953, já a questão do método aparece em seu próprio título).

O método de Matoré inclui inicialmente o estabelecimento de recortes temporais, que devem considerar a noção de geração, que compreende faixas de tempo de 30 a 36 anos (p. 56-59). Esses "recortes racionais" devem ser fixados com base em datas importantes na história do léxico e da sociedade (e não simplesmente em datas da histórica política). Em seguida, são identificados em cada faixa de tempo campos nocionais (conjunto de palavras), baseados no "parentesco sociológico dos elementos" (p. 64-65). Os elementos que formam esses campos são as palavras-testemunho (elementos particularmente importantes em função dos quais a estrutura lexicológica se hierarquiza e se coordena): a palavra-testemunho é "um símbolo material de um fato espiritual importante, é a concretização de um fato de civilização" (p. 65-66). Ela não é caracterizada apenas por seu valor estático no interior do campo, pois manifesta também um dinamismo: "a palavra-testemunho é o símbolo de uma mudança, (...) é um neologismo; a mutação brusca que lhe dá nascimento é o sinal de uma nova situação social econômica, estética, etc.: ela marca uma virada" (p. 66, itálicos do ori- 
ginal). Como são muitas as palavras-testemunho, devem-se classificar os campos nocionais com base em palavras-chave (uma noção de caráter social que expressa de maneira sintética a época estudada): essas palavras são "unidades lexicológicas que exprimem uma sociedade, consistem em um ser, um sentimento, uma ideia em que a sociedade reconhece como um ideal" (p. 67). As palavras-chave são divididas em principal e secundárias (p. 69), existindo entre elas uma hierarquia.

Com base nesse método, é possível descrever campos nocionais de cada época, cujos elementos estão ordenados segundo fatores de ordem sociológica. Como exemplo, veja-se a seguir uma reprodução do campo nocional de arte e artista por volta de 1765 (FIG. 1) e por volta de 1827-1834 (FIG. 2), ambos elaborados por Matoré:

\section{FIGURA 1}

O campo nocional de arte e técnica por volta de 1765

(MATORÉ, 1973, p. 102)

LE CHAMP NOTIONNEL D'ART ET DE TECHNIQUE VERS 1765

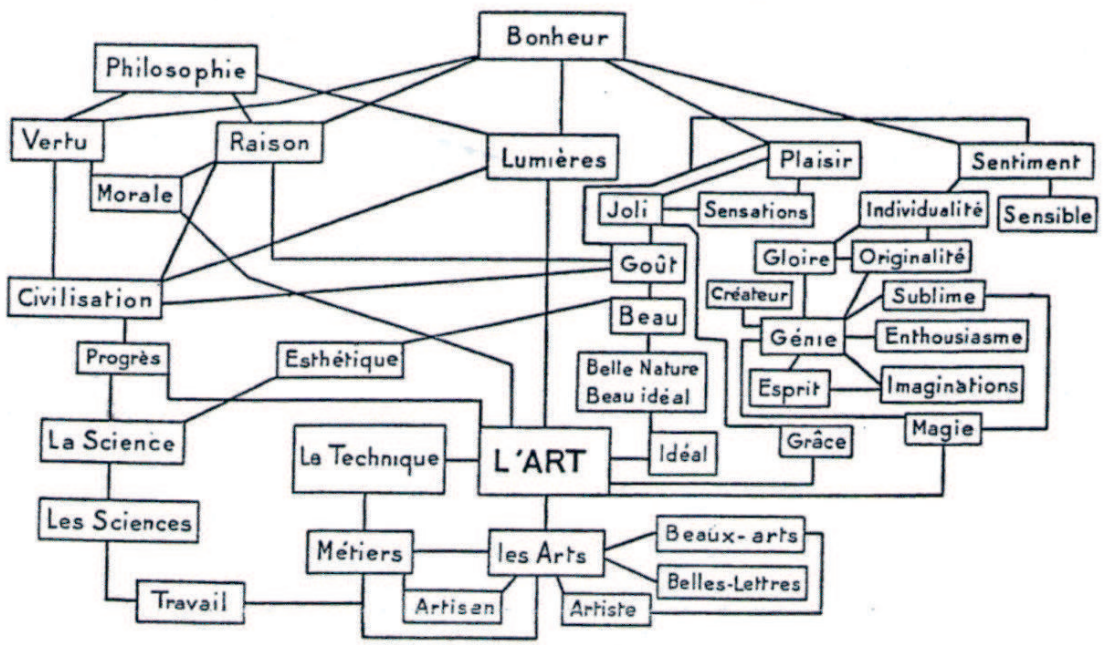


FIGURA 2

O campo nocional de arte e artista por volta de 1827-1834

(MATORÉ, 1973, p. 116)

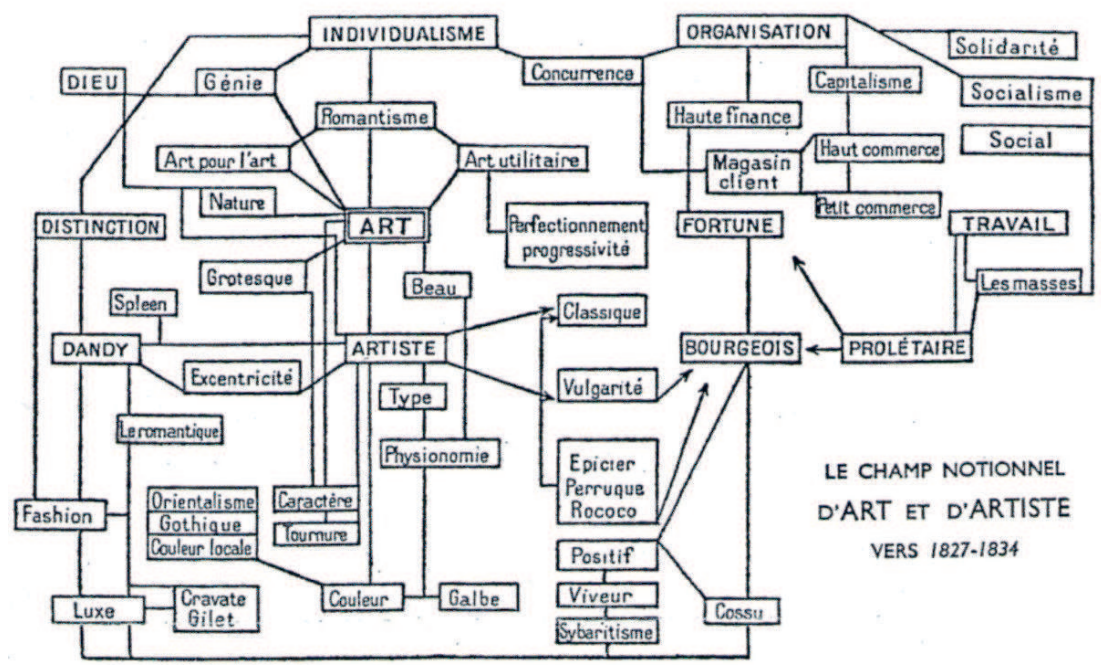

\subsection{As principais críticas}

Das críticas que a proposta de Matoré recebeu, certamente a principal foi a de que sua abordagem não seria propriamente uma análise linguística. Essa crítica apareceu com diversos matizes: Coseriu (1967) considerou que o campo de Matoré não constituía uma estrutura linguística, mas, sim, uma configuração associativa (entre idéias, e não entre itens lexicais), e que análise de Matoré não se situava no sistema da língua (nível das oposições distintivas), mas sim na norma (nível dos usos); Geckeler (1976, p. 202-205) censurou o método de Matoré por estabelecer oposições que eram de natureza sociológica e não linguística e ainda por não realizar nenhuma análise semântica dos lexemas; Gordon (1982, p. 143) era de opinião que as ditas estruturas sociológicas de Matoré não tinham nada a ver com traços inerentes ou intrínsecos do léxico, sendo, na verdade, seu verdadeiro objeto de estudo as crenças, os interesses e preocupações de várias eras da história social tal como se refletem na língua - não teria explicado nada com seu método, apenas teria afirmado existir correlação entre fatos linguísticos e sociais. 
Uma segunda crítica recorrente foi a de que haveria arbitrariedade (ou vaguidão) no processo de delimitação e de hierarquização dos elementos que comporiam um campo nocional: Spencer (1961) assinalou que os limites dos campos de Matoré pareciam arbitrários do ponto de vista sociológico e linguístico; Geckeler (1976, p. 202-205) reprovou o método, por investigar algo que não se poderia delimitar (palavras dentro da totalidade do vocabulário); e Gordon (1982, p. 133-143) questionou como um critério tão amplo como o de natureza sociológica poderia determinar a estrutura inteira do vocabulário (no campo nocional de arte e artista, constam apenas substantivos e adjetivos), chamou a atenção para o fato de não ter determinado como os limites de um grupo de palavras pode ser estabelecido nem tampouco como é determinada a posição relativa das palavras nos campos (cf. as linhas que ligam as palavras em cada campo) e assinalou que Matoré não chegou a precisar a natureza da hierarquia lexical: como determinar concretamente o que deve ser considerado palavra-chave e palavra-testemunho?

Uma crítica mais técnica foi a de que a adoção de recortes temporais de 30 a 36 anos (baseados na teoria das gerações) era um procedimento externo à realidade linguística: Iordan (1973, p. 556-557) considerou a proposta como um conceito inútil no campo linguístico e histórico-literário, enxertado artificialmente na evolução histórico-social, não valorizando o caráter processual da história; e Geckeler (1976, p. 202-205) achou equivocado supor que o vocabulário muda no ritmo de gerações.

Outro aspecto criticado foi a concepção de que o método seria sincrônico (nos termos de Matoré (1973, p. 13), "a lexicologia (...) visa a grupos de palavras considerados estaticamente do ponto de vista nocional"): Iordan (1973, p. 556-557) e Gordon (1982, p. 139) assinalaram que a noção de palavra-testemunho (um neologismo que marca uma transformação social) era essencialmente de natureza diacrônica.

Uma crítica interessante foi feita por Robin (1977, p. 40-44), que considerou que Matoré se baseou no "postulado da transparência das estruturas sociais aos agentes que são seus suportes", ou seja, tomou o "discurso dos homens do passado [e] suas justificações, como chave de seus comportamentos e de suas maneiras de agir e de pensar". Para ela, os campos nocionais (por exemplo, o de honra no séc. 18) revelariam, na verdade, "a organização discursiva das classes dirigentes, como efeito da ideologia nobiliária, como efeito do sistema de representação próprio da classe dominante". Nessa linha de argumentação, chamou ainda atenção para o fato de que seria a ingenuidade de considerar um isomorfismo entre léxico e grupos sociopolíticos, pois um locutor é capaz de utilizar o 
modelo de performance de outros grupos sociais por meio de simulações e mascaramentos.

Entre inconsistências na exposição de Matoré assinalados por Gordon (1982, p. 134), convém também assinalar a alegada circularidade na descrição da relação entre léxico e sociedade: ora se disse que se deve partir do vocabulário para explicar a sociedade, ora se afirmou que são os fatos sociais que explicam a estrutura lexical; ora se considerou que o estudo do léxico deve buscar dados relevantes do ponto de vista social, ora se defendeu que o estudo deve se restringir a dados de natureza social.

A essas críticas precedentes, podem-se acrescentar aqui algumas novas críticas.

Primeiramente ficou vago qual foi o corpus que utilizou para identificar as palavras-testemunho (as que representam as transformações sociais). Naturalmente Matoré não terá considerado a totalidade do léxico de francês de cada época: quem é capaz de conhecer algo tão vasto? As repetidas menções a escritores (por exemplo, Hugo, Balzac) e filósofos (por exemplo, Montaigne, Diderot) em sua obra sugerem terem sido as obras destes sua fonte fundamental para dados, o que chama a atenção, já que ele mesmo assinala que os escritores não seriam os principais responsáveis pelos neologismos. ${ }^{3}$

Em segundo lugar, não ficou claro se, para cada recorte temporal, haveria apenas um campo nocional passível de estabelecimento. Caso sim, parece estranho que se consiga articular ou associar em apenas um campo as diversas palavras-testemunho que representam transformações por que passou um sociedade: estariam elas sempre correlacionadas a ponto de justificar existir apenas um campo? Caso não, quantos são os campos nocionais possíveis de serem estabelecidos por recorte temporal? Estariam eles também em uma relação de hierarquia entre si? Matoré apresenta uma classificação de base social para o léxico de 1765 (MATORÉ, 1973, p. 77-79), cujos elementos não estão todos presentes no campo nocional de arte e técnica por volta de 1765 (MATORÉ, 1973, p. 102): no campo aparece aproximadamente apenas a metade! Ou houve uma falha grave na aplicação do método ou se esqueceu de esclarecer que cada recorte temporal comporta mais de um campo.

Em terceiro lugar, retomando um argumento apenas citado mas não desenvolvido por Robin (1977, p. 41), Matoré utiliza o termo sociedade de uma forma vaga. Quem são os integrantes dessa sociedade a que ele se refere? Se se considerar que o corpus que Matoré supostamente terá tomado como fonte de fatos se compunha textos de escritores e filósofos, constata-se que Matoré tinha 
como referência uma parcela bastante limitada do complexo tecido social. Partese de um pressuposto equivocado de homogeneidade da realidade social: todas as classes sociais em todas as regiões da França experimentariam as mesmas transformações históricas ao mesmo tempo e em todo o espaço geolinguístico, por isso o léxico de uma parcela (escritores e filósofos) é suficiente para representar o todo. Pode-se dizer que a lexicologia de Matoré é social (pois considera as transformações no mundo real ao analisar a língua, mais especificamente, o léxico), mas não é sociolinguística (pois não considera as diferenças na sociedade - de gênero, de idade, de classe social, de região, de formação escolar, etc. - ao analisar o léxico).

\section{Em direção a uma lexicologia sócio-histórica}

As duras críticas à lexicologia social de Matoré não deram origem a um modelo teórico-metodológico que tenha conseguido superar os problemas identificados e sucedê-lo como marco de referência para estudo do léxico em uma perspectiva social. O próprio Matoré (1973, p. 91), no entanto, já havia deixado claro em sua obra que o estado incipiente dos estudos lexicológicos de então não lhe permitiam apresentar mais do que hipóteses.

As propostas posteriores de fundo estruturalista que levaram adiante a produtiva noção de campo linguístico, como a dos campos léxicos de Coseriu, ${ }^{4}$ praticamente excluíram o que seria o traço mais distintivo da proposta de Matoré: o seu forte compromisso com a realidade social. Por um lado, apresentaram critérios mais objetivos de delimitação do mesmo campo lexical (por exemplo, partilhar um sema comum), mas, por outro lado, enfraqueceram fortemente a capacidade de explicar as mudanças lexicais em razão da exclusão da questão social na interpretação da constituição e organização do léxico. No fundo, esses outros modelos estruturais constituem fundamentalmente modelos de descrição do léxico, pois falham em explicar como o léxico vem a constituir-se: o que, por exemplo, faz um item lexical ganhar ou perder um sema? o que leva um falante a criar uma palavra para um conceito para o qual já existia uma palavra? Os modelos estruturais (internalistas) como o dos campos léxicos não respondem a questões como estas.

$\mathrm{Na}$ seção que se segue, pretende-se mostrar, por meio de um estudo caso, que um modelo de organização e funcionamento do léxico (incluindo-se aí a questão das mudanças lexicais) não pode prescindir da articulação de fatores 
intralinguísticos e extralinguísticos. Essa articulação, já bem assentada nos estudos de mudança linguística em uma orientação laboviana, tem sido lamentavelmente negligenciada em estudos do léxico.

\subsection{Um estudo de caso: de esquadrão da morte a grupo de extermínio}

Por volta da década de 60 no Brasil, difunde-se a expressão esquadrão da morte (= EM) com o sentido específico de "grupo de policiais que cometem execução sumária". Posteriormente difunde-se a expressão grupo de extermínio (=GE), que, aparentemente, seria usada com valor equivalente. ${ }^{5}$ A questão central aqui é: o que o percurso histórico dessas expressões revela em relação ao processo de criação e incorporação de neologismos ao léxico de uma língua? Ademais, importa discutir também que estratégias metodológicas devem ser utilizadas para compreender mais adequadamente esses fenômenos.

\subsubsection{Questões metodológicas}

Para se poder conseguir rastrear os meandros da mudança lexical com mais detalhe, desponta como opção produtiva de corpus a mídia impressa, cujo papel em termos de influência sobre o léxico da sociedade tem sido reiteradamente reconhecido (CARVALHO, 1984, p. 13; ALVES, 1990, p. 8-9). Assim sendo, adotou-se aqui um corpus formado por três veículos da mídia impressa que disponibilizam seu acervo on-line: os jornais diários Folha de São Paulo (= FSP) [http://acervo.folha.com.br] e Estado de São Paulo (= ESP) [http://acervo.estadao.com.br] e ainda a revista semanal Veja $(=\mathrm{VJ})$ [http://veja.abril.com.br/acervodigital]. Em função dos autores dos textos (essencialmente jornalistas), pode-se supor que o léxico considerado diga respeito a um grupo social com escolaridade, predominantemente de estrato socioeconômico intermediário, do sexo masculino, de faixa etária adulta, do Estado de São Paulo, utilizando estilo formal: tais inferências são confirmadas por alguns dados no próprio texto (como o nome do jornalista e a filial a partir da qual escreve).

No que diz respeito ao recorte temporal, rejeita-se aqui a proposta de Matoré (tão criticada) de faixas de 30 a 36 anos, pois parecem não apenas linguisticamente arbitrárias como sobretudo excessivamente extensas: quanta informação específica sobre a criação dos neologismo não se deixa de perceber por recortes tão amplos? Embora o corpus permita um acompanhamento diário dos dados, um recorte tão curto também não há de ser produtivo, pois não deve haver mudanças lexicais relacionadas a EM e GE necessariamente todo dia. Adota-se 
experimentalmente uma faixa de 5 anos: não tão curta a ponto de dificultar a percepção de tendências gerais, nem tão extensa a ponto de impedir a percepção de qualquer tendência. Diferentemente de Matoré, a determinação do limite não será feita com base em critérios extralinguísticos, mas, sim, com um critério intralinguístico: o primeiro ano em que aparece o EM (a mais antiga das duas expressões) com o significado específico de "grupo de policiais que cometem execução sumária”.

Um dos aspectos considerados como marca estruturalista da proposta de Matoré é a visão sistêmica de léxico, visão na qual está fundamentada a noção de campo nocional. No presente estudo de caso não será possível analisar as expressões EM e GE dentro de algum campo nocional específico, pois a seleção dos demais elementos do campo nocional a que pertenceriam pressupõe terem-se sanados justamente problemas metodológicos que o estudo de caso específico se propõe a analisar, ou seja, apenas após a conclusão do estudo de caso será possível a elaboração de estratégias de reconhecimento de um campo nocional

Antes de apresentar os dados, convém esclarecer alguns outros aspectos da análise. Uma vez determinado o corpus, fez-se busca com as expressões esquadrão da morte (=EM) e grupo de extermínio (=GE), em sua forma por extenso (no singular e no plural) por ano e buscaram-se, no texto em que ocorrem, dados que pudessem revelar as particularidades semânticas de cada uma. No período de 2004 a 2012 não foram computados dados da FSP, por limitações técnicas da base. A data de início de publicação de cada veículo analisado é 04/01/1875 (ESP), 01/01/1960 (FSP) e 11/09/1968 (VJ). As transcrições seguem ortografia da época e nomes próprios são substituídos por siglas respectivas (exceto em casos especiais).

\subsubsection{Descrição e discussão dos dados}

Levando em conta o corpus, identificou-se que a primeira ocorrência de EM foi em 1915: ${ }^{6}$

Ao mesmo tempo, [Tenente] A., com cincoenta homens, dá a ultima carga. O esquadrão da morte cáe fulminado. Só elle, ferido, não morre, porque os allemães se apressam em aprisional-o. (ESP, 20/09/1915, p. $4 \_$excerto, itálico nosso).

Esta ocorrência refere-se a um episódio da batalha de Naulila, em que tropas portuguesas combatem tropas alemãs em disputa territorial em Angola. O sentido aqui ("pelotão do exército em batalha") ainda não é o que é objeto deste 
estudo de caso ("grupo de policiais que cometem execução sumária"). Levando em conta que o corpus remonta ao ano de 1875 , essa atestação não deixa de registrar, no entanto, um neologismo (de forma).

É somente em 1961 que aparece no corpus a primeira ocorrência de EM com o sentido de "grupo de policiais que cometem execução sumária":

\begin{abstract}
ADIADO O JULGAMENTO DO “ESQUADRÃO DA MORTE" Rio, 29 (FSP) - Por não terem comparecido as testemunhas arroladas pelo Ministério Público, foi adiado "sine die" o julgamento do denominado "esquadrão da morte", integrado pelos policiais E. M. de S., I. J. de O., S. C. de O. e J. de D. D., denunciados como autores da morte do motorista E. F. de O. (FSP, 30/03/1961, Prim. cad., p. 5 , excerto, itálicos meus).
\end{abstract}

Trata-se do julgamento de policiais civis acusados de assassinar um motorista da TV Tupi em 28 de fevereiro de 1958. Esses policiais pertenciam ao Serviço de Diligências Especiais (SDE), subordinado ao então chefe de polícia da Guanabara, general Amaury Kruel7. Segundo Rose (2005, p. 233-234), o SDE teria passado a receber o apelido de Esquadrão da Morte na imprensa por Amado Ribeiro, jornalista do periódico carioca Última Hora. ${ }^{8}$

Depois dessa única ocorrência em 1961, é só a partir de 1967 que a expressão volta a aparecer no corpus com o significado aqui considerado. A partir de 1967, a expressão passa a ocorrer de forma ininterrupta ao longo dos 45 anos seguintes. A primeira ocorrência de EM a partir de 1967 em cada um dos veículos da mídia impressa é a seguinte:

\footnotetext{
"Esquadrão da Morte" na caça aos assassinos do motorista Agentes do 'Esquadrão da Morte' - equipe da Delegacia de Roubos que pode matar - voltam sua atenção para o assassínio de J. A. dos S. (36 anos, casado), motorista de praça que ladrões mataram sábado, no km 33 da estrada que liga Jandira a Itapevi. (FSP, 10/04/1967, ed. da tarde, p. 6, negrito do original, itálicos nossos).
}

Só no segundo semestre deste ano, na Baixada Fluminense, o sistema adotado principalmente pelos chamados "esquadrões da morte" deve ter provocado mais de duzentas mortes. (VJ, 20/11/1968, ed. 11, p. 26, excerto, itálicos nossos). 
“O Esquadrão da Morte existe? (...) A verdade: oficialmente, não há nenhum esquadrão da morte aqui em São Paulo. Há, isto sim, um grupo grande de investigadores, de tôdas as delegacias, que está disposto a matar antes de ser morto. É a guerra contra o crime, que a Polícia vinha perdendo, porque - como a própria Secretaria de Segurança Pública reconheceu na nota oficial divulgada anteontem está desatualizada. (ESP, 28/11/1968, Nac., p. 28, excerto, negritos do original $)^{9}$.

A primeira ocorrência de GE em cada veículo do corpus se dá na década de $70^{10}$ :

O govêrno federal, ao que se adianta, está convencido da necessidade de se decretar o paradeiro definitivo das atividades dêsse grupo de extermínio, cujos crimes repercutem no exterior com resultados negativos para a imagem do País. (ESP, 01/08/1971, p. 39, excerto, itálicos nossos).

À parte essa falha insanável do ponto de vista jurídico - a de arrolar os crimes de um grupo de extermínio que, aparentemente, não exterminou ninguém -, êle parecer ter incidido em outro vício também grave. (VJ, 29/09/1971, ed. 160, p. 26, excerto, itálico nosso).

O grupo de extermínio que age na baixada Fluminense está sendo responsabilizado por 75 "crimes misteriosos", mas o fato não merecer ainda nenhum pronunciamento do Secretário de Segurança, general B. M. (FSP, 23/08/1977, Prim. cad., p. 24, excerto, itálico nosso).

As ocorrências de EM e GE em FSP, ESP e VJ apresentaram os seguintes valores absolutos (n) e relativos (\%) em relação à faixa de tempo de 1961 a 2010: ${ }^{11}$ 
TABELA 1

Formas por mídia e por faixa de tempo (n)

\begin{tabular}{|l|r|r|r|r|r|r|r|r|r|r|r|r|}
\hline & \multicolumn{4}{|c|}{ EM } & \multicolumn{4}{|c|}{ GE } & \multicolumn{4}{|c|}{ EM+GE } \\
\cline { 2 - 15 } & FSP & ESP & VJ & Total & FSP & ESP & VJ & Total & FSP & ESP & VJ & Total \\
\hline $\mathbf{1 9 6 1 - 1 9 6 5}$ & 1 & 0 & - & 1 & 0 & 0 & - & 0 & 1 & 0 & - & 1 \\
\hline $\mathbf{1 9 6 6 - 1 9 7 0}$ & 288 & 126 & 48 & 462 & 0 & 0 & 0 & 0 & 288 & 126 & $\mathbf{4 8}$ & 462 \\
\hline $\mathbf{1 9 7 1 - 1 9 7 5}$ & 346 & 259 & 76 & 681 & 0 & 1 & 1 & 2 & 346 & 260 & 77 & 683 \\
\hline $\mathbf{1 9 7 6 - 1 9 8 0}$ & 798 & 185 & 105 & 1088 & 13 & 17 & 4 & 34 & 811 & 202 & 109 & 1122 \\
\hline $\mathbf{1 9 8 1 - 1 9 8 5}$ & 621 & 155 & 22 & 798 & 23 & 25 & 6 & 54 & 644 & 180 & 28 & 852 \\
\hline $\mathbf{1 9 8 6 - 1 9 9 0}$ & 301 & 120 & 13 & 434 & 93 & 71 & 3 & 167 & 394 & 191 & 16 & 601 \\
\hline $\mathbf{1 9 9 1 - 1 9 9 5}$ & 350 & 91 & 19 & 460 & 247 & 162 & 21 & 430 & 597 & 253 & 40 & 890 \\
\hline $\mathbf{1 9 9 6 - 2 0 0 0}$ & 88 & 208 & 5 & 301 & 178 & 191 & 5 & 374 & 266 & 399 & 10 & 675 \\
\hline $\mathbf{2 0 0 1 - 2 0 0 5}$ & 88 & 193 & 3 & 284 & 116 & 216 & 7 & 339 & 204 & 409 & 10 & $\mathbf{6 2 3}$ \\
\hline $\mathbf{2 0 0 6 - 2 0 1 0}$ & - & 116 & 11 & 127 & - & 228 & 8 & 236 & - & 344 & 19 & 363 \\
\hline Total & $\mathbf{2 8 8 1}$ & $\mathbf{1 4 5 3}$ & $\mathbf{3 0 2}$ & $\mathbf{4 6 3 6}$ & $\mathbf{6 7 0}$ & $\mathbf{9 1 1}$ & $\mathbf{5 5}$ & $\mathbf{1 6 3 6}$ & $\mathbf{3 5 5 1}$ & $\mathbf{2 3 6 4}$ & $\mathbf{3 5 7}$ & $\mathbf{6 2 7 2}$ \\
\hline
\end{tabular}

GRÁFICO 1

Formas por faixa de tempo (\%)

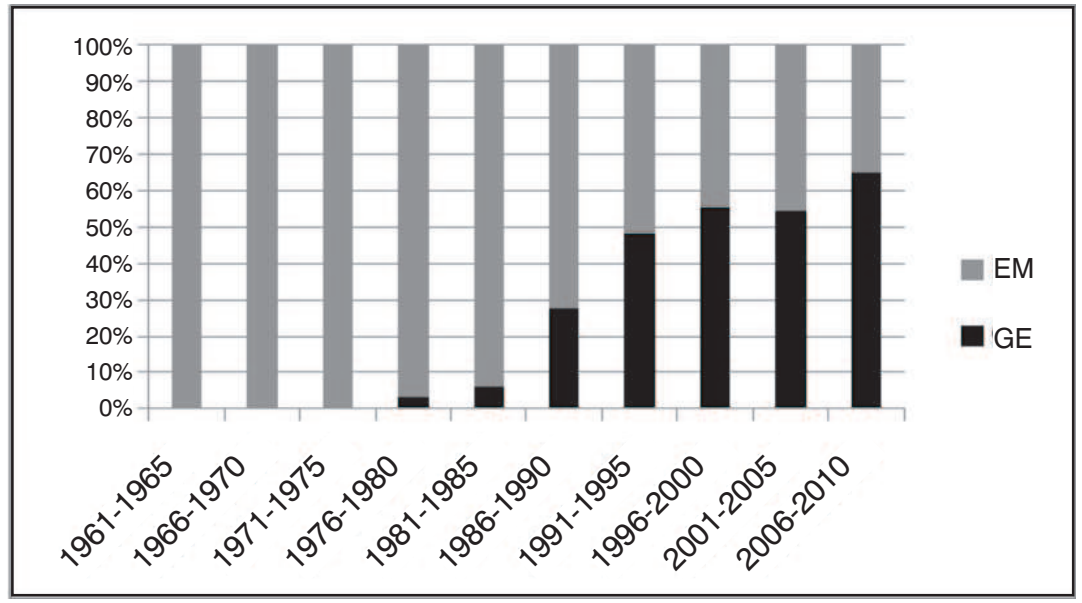

Mais elucidativos do que os absolutos são os números relativos, que indicam claramente que EM é prevalente entre 1961 e 1990, quase equitativo com GE entre 1991 e 2005 e minoritário em relação a GE entre 2006 e 2010. 
Seja por meio dos números absolutos, seja por meio dos números relativos, fica claro que EM predomina sobretudo ao longo do período da ditadura no Brasil (1964-1985) enquanto GE tem sua prevalência no período posterior a ela. A associação entre as práticas de execução realizadas pelos grupos chamados de EM e o período da ditadura no Brasil tem sido, aliás, convergente entre diferentes pesquisadores (LANGGUTH, 1979, p. 216; BLUM, 2004, p. 170-171; REALE JR., 2007, p. 2; CUNHA, 2012). O paralelismo EM/período da ditadura e $\mathrm{GE} /$ período posterior à ditadura sugere que o léxico estaria marcando uma mudança social, como preconizava Matoré: no caso específico, mudou-se o regime político e consequentemente houve mudança no léxico. Matoré defendia que o neologismo reflete uma transformação social, mas o aparecimento do neologismo de sentido de EM como "grupo de policiais que cometem execução sumária" se dá no corpus em março de 1961, havendo, porém, registro fora do corpus adotado de uso já em março de 1959 (em UH), antes, portanto, do início da ditadura no Brasil em 31 de março de 1964. Uma hipótese seria dizer que a transformação social que o neologismo EM reflete não está associada à ditadura, pois é-lhe anterior - hipótese que entraria em conflito com a já assinalada associação convergente entre ambos. Uma segunda hipótese seria defender que não é simplesmente a criação de um neologismo que marca uma transformação social, mas também sua difusão pela sociedade - neste caso, a associação entre a expressão EM e o período da ditadura seria mantida, pois não só é a partir de 1967 que o uso de EM passa a ser contínuo com o sentido aqui considerado, como também é por volta do fim da ditadura que essa expressão começa a perder vitalidade (a primeira queda de EM em números absolutos se dá na faixa 1981-1985, período semelhante ao do mandato do último presidente militar, entre 1979 e 1985).

O problema da sincronização entre neologismos e transformações sociais apresenta ainda outra faceta. Matoré, com base na teoria das gerações (faixas de tempo de 30 a 36 aos), defendeu que as mudanças no léxico seriam "bruscas", mas o caso em estudo mostra que a mudança não foi exatamente brusca: a criação de EM como neologismo de sentido não foi seguida de uma adoção ampla imediata, pois, tendo ocorrido pela primeira vez no corpus em 1961, só volta a aparecer em 1967. É fato, porém, que a partir de 1967 seu uso apresenta aumento notável (novamente o aspecto linguístico do léxico que parece mais saliente aqui não é a criação do neologismo mas, sim, a difusão). Curiosamente, também em relação a GE constata-se a oposição entre criação e difusão: a primeira ocorrência no corpus foi em 1971, mas sua difusão só se deu a partir de 1977. Em ambos os casos, há um lapso de tempo aproximado de 6 anos entre o aparecimento dos neo- 
logismos de sentido (de EM e de GE) e sua efetiva difusão (representada pelo aumento na frequência): entre 1961 e 1967 para EM e entre 1971 e 1977 para GE. Nos dois casos, as faixas de tempo de 30 a 36 anos propostas por Matoré não são pertinentes: do aparecimento de EM como neologismo de sentido (por volta de 1961) até o de GE igualmente como neologismo de sentido em 1971 passaramse 10 anos apenas. Em síntese, os dois fenômenos linguísticos relativos ao léxico aconteceram em um período de aproximadamente 10 anos um do outro.

Um aspecto importante a ser considerado em relação ao percurso histórico de EM e GE é se essas designações seriam variantes, ou seja, se teriam o mesmo significado (se seriam "formas diferentes de dizer o mesmo", nos termos de Labov (1972, p. 188)).

A relação semântica entre as expressões EM e GE não parece ter sido suficientemente discutida ainda. Segundo Rose (2005, p. 295), haveria uma diferença estilística entre esquadrão da morte e grupo de extermínio: "O nome do Esquadrão ainda era invocado de tempos de tempos, mas por volta de meados dos anos 80 a referência mais polida a justiceiros de subelite tornou-se grupo de exterminio" (tradução nossa). Essa interpretação da relação entre as formas sugere que sejam realmente variantes, pois teriam o mesmo significado. A identidade de sentido parece também ser defendida na seguinte passagem:

Para Ivan Seixas [presidente do Conselho de Defesa da Pessoa Humana (Condepe)], os grupos de extermínio de hoje e o esquadrão da morte da ditadura "são a mesma coisa, só que com outro nome. Supostamente começa para matar bandidos e vira terrorismo de Estado.”. (MERLINO, 2012, p. 13, itálico nosso).

GE como neologismo de sentido, porém, não parece ter sido formado como um sinônimo (e, portanto, uma variante) de EM, mas, sim, como um hiperônimo (um termo mais genérico). EM seria quase um nome próprio, pois designava no início um grupo específico no Rio (o SDE de Kruel) em fins da década de 50; mas a proliferação de grupos de igual tipo - cada qual se autointitulando de forma específica (por exemplo, Rosa Vermelha no Rio de Janeiro e Lírio Branco em São Paulo entre os anos de 1968 e 1969 (MONTEIRO; BARBOSA, 1980, p. 89)) - teria levado os falantes a criar um termo genérico para poderem fazer referência conjuntamente aos diferentes grupos policiais de execução que foram se constituindo ao longo do tempo. É importante salientar que a expressão GE surgiu apenas após a proliferação de grupos policiais de execução: é essa cronologia que legitima a presente proposta de primeira motivação para a criação do 
neologismo. Vê-se, portanto, que o neologismo de sentido em questão está, de fato, refletindo uma transformação social: a proliferação dos referidos grupos.

Como hiperônimos costumam ser usados como recurso estilístico para evitar repetições em um mesmo texto (desempenhando função de coesão textual), tal função também foi acumulada por GE: nas suas três primeiras ocorrências no corpus (cf. dados (6) a (8)), GE aparece sempre depois de ter sido mencionada a expressão EM - as menções nos textos com as três primeiras ocorrências de GE apresentam a seguinte ordem de formas: $\mathrm{EM}>\mathrm{GE}>\mathrm{E}$ (squadrão) $>\mathrm{EM}$ (ESP, 01/08/1971, p. 39); EM > E > E > E > GE (VJ, 29/09/1971, ed. 160, p. 26); E [título] $>$ EM $>$ GE $>$ EM $>$ EM (FSP, 23/08/1977, Prim. cad., p. 24).

Essas duas motivações para a formação de GE (expressar um fato de forma genérica e evitar repetição de termo) não dão conta de um aspecto importante: se os grupos de execução eram sabidamente de policiais, porque se abriria mão de uma expressão com o termo esquadrão, que sempre esteve associado a força pública de segurança do Estado (fossem tropas, fossem policiais), por uma expressão cujo núcleo - grupo - é um termo sem qualquer associação semântica com a noção de força pública de segurança?

$\mathrm{O}$ fato de se ter formado um neologismo com elemento tão genérico grupo - parece ter uma motivação de ordem fundamentalmente sócio-histórica. O neologismo GE aparece no corpus a partir de 1971 e foi justamente no período da primeira metade da década de 70 que instituições do Estado passaram efetivamente a atuar na repressão à prática da execução por policiais em função da proliferação dos grupos, sendo o símbolo-mor dessa atuação o então Procurador de Justiça Hélio Bicudo, cujas ações de apuração se iniciaram já em princípios de 1969, mas com condenações somente a partir de fins da década de 70 (BICUDO, 1976). A ação do Estado na repressão aos grupos policiais de execução levou a uma mudança radical no comportamento desses grupos: passou-se de uma prática exibicionista para uma prática velada. Veja-se que, no início das práticas de execução, o EM tinha sua identidade praticamente evidente na mídia ("Agentes do 'Esquadrão da Morte' - equipe da Delegacia de Roubos que pode matar - voltam sua atenção para o assassínio de J. A. dos S." [FSP, 10/04/1967, ed. da tarde, p. 6, itálico nosso]), fazia uso até mesmo de "relações públicas" ("O corpo do marginal, segundo um telefonema feito no sábado ao delegado A. B. por um indivíduo que se identificou como o 'relações públicas' do Esquadrão, está sendo procurado, perto do morro do Jaraguá." [FSP, 02/12/1968, ed. da tarde, p. 01]) e não raramente deixava cartazes junto aos executados, assumindo a autoria ("Em cartaz de cartolina branca onde havia o tosco desenho de uma caveira com dois ossos 
cruzados, as inscrições ‘E.M.' e ‘S.P.”' [FSP, 07/12/1968, prim. cad., p. 1]). Após a intensificação da repressão aos grupos, o exibicionismo ${ }^{12}$ vai rareando até chegar-se a uma situação de grande nebulosidade, motivada certamente pela intenção de ocultar qualquer traço de identificação da natureza das mortes, fazendo parecer até mesmo com conflitos entre criminosos. Rose (2005, p. 295) também reconhece essa mudança: "Amostras ostentosas de desdém e impunidade se tornaram mais e mais infrequentes (...). Em parte, isso aconteceu por causa da má impressão que tal comportamento produziu no exterior." (tradução nossa). Em síntese, uma terceira motivação para a criação do neologismo de sentido GE foi a própria mudança no comportamento dos grupos policiais de execução, que pararam de assumir publicamente suas execuções.

As três motivações aqui apresentadas para a origem do neologismo GE mostram uma interação interessante entre motivações internas (expressar um fato de forma genérica e evitar repetição de termo) e externas (mudanças na realidade que EM designava originalmente). Assim, longe de aparecerem aleatoriamente no léxico de uma língua, os neologismos parecem apresentar um percurso específico na sua integração à estrutura do léxico.

A complexa história dos neologismos EM e GE apresenta, porém, mais um outro capítulo. Como se demonstrou acima, o surgimento de GE como neologismo de sentido deu-se em um momento de repressão aos grupos policiais de execução, época em que a natureza dos membros dos grupos passa ser cada vez menos evidenciada por eles próprios (desaparecem os cartazes juntos aos executados, os seus "relações públicas" deixam de ligar para as delegacias e redações de jornal para informar a localização dos executados, etc.). Esse velamento, no entanto, ocorre simultaneamente a uma outra mudança importante, assinalada pelo já referido Hélio Bicudo:

O "esquadrão da morte" foi uma iniciativa da Polícia Civil (...). Mas, de uma maneira ou de outra, a experiência da Polícia Civil foi assimilada pela Polícia Militar, a qual, com incrível desenvoltura, invadiu aquela seara e passou a matar marginais e criminosos, com o estímulo de uma Justiça Militar cuja competência se ampliou indevidamente, para julgar crimes de policiamento e no policiamento, até então entregues à Justiça Comum.” (BICUDO, 1988, p. 12-13).

Como esse relato de Bicudo revela uma transformação na sociedade, pode-se questionar se ela também terá afetado os usos de EM e GE. Como existe um paralelismo em termos de mudança de predomínio da expressão EM para a 
de GE e da autoria das execuções de PC para PM, pode-se aventar a hipótese de que as duas mudanças estejam efetivamente relacionadas, ou ainda mais especificamente, que a mudança na autoria das execuções tenha se refletido na língua também pela mudança na preferência do uso de EM pela de GE.

Para verificar essa hipótese, recorreu-se aos dados coletados nos veículos da mídia impressa aqui consultados. Considerando a grande quantidade de dados (6272 ocorrências), optou-se por verificar-se a questão por amostragem: um texto por ano para cada veículo da mídia impressa analisado. Escolheu-se sempre o texto com a primeira ocorrência das expressões em cada ano; caso não houvesse identificação da natureza do acusado de autoria, considerou-se o texto imediatamente seguinte no tempo. Nesta análise por amostragem, consideraramse apenas FSP e VJ, pois a consulta a cada texto em ESP não é aberta (a busca de dados e a sua frequência são serviços abertos; mas a consulta ilimitada a cada texto, não). A quantificação levou em conta apenas a natureza do acusado de fazer parte do grupo de execução e não o número de acusados por tipo em questão: assim, para textos em que se mencionassem vários acusados de uma mesma natureza, o valor atribuído foi apenas 1 , em função de tratar-se de apenas um único e mesmo tipo (em um mesmo texto, porém, podem aparecer mais de um tipo). O reconhecimento da natureza deu-se por três métodos: menção explícita (identificação da corporação: por exemplo, Polícia Militar), menção metonímica (menção do cargo na corporação: por exemplo, investigador [= Polícia Civil]) ou conhecimento partilhado (menção do nome próprio do acusado, cuja filiação já era conhecimento geral na mídia da época: por exemplo, Sérgio Paranhos Fleury [= Polícia Civil]). Os resultados obtidos foram os seguintes em números absolutos (n) e relativos (\%) [legenda: $\mathrm{P}=$ Polícia (sem especificação); PC = Polícia Civil; $\mathrm{PM}=$ Polícia Militar; $\mathrm{O}=$ Outros]: 
TABELA 2

Formas por natureza do acusado e por faixa de tempo (n)

\begin{tabular}{|c|c|c|c|c|c|c|c|c|c|c|c|c|c|c|c|}
\hline & \multicolumn{5}{|c|}{ EM } & \multicolumn{5}{|c|}{$\overline{G E}$} & \multicolumn{5}{|c|}{$\overline{E M+G E}$} \\
\hline & $\mathbf{P}$ & PC & PM & $\mathbf{0}$ & Total & $\mathbf{P}$ & PC & PM & 0 & Total & $\mathbf{P}$ & PC & PM & 0 & Total \\
\hline 1961-1965 & $\overline{0}$ & 1 & 0 & 0 & 1 & 0 & 0 & 0 & 0 & 0 & 0 & 1 & 0 & 0 & 1 \\
\hline $1966-1970$ & 1 & 6 & 0 & 1 & 8 & 0 & 0 & 0 & 0 & 0 & 1 & 6 & 0 & 1 & 8 \\
\hline 1971-1975 & 1 & 9 & 0 & 1 & 11 & 0 & 0 & 0 & 0 & 0 & 1 & 9 & 0 & 1 & 11 \\
\hline $1976-1980$ & 2 & 8 & 0 & 3 & 13 & 1 & 1 & 3 & 2 & 7 & 3 & 9 & 3 & 5 & 20 \\
\hline 1981-1985 & 3 & 6 & 3 & 0 & 12 & 1 & 1 & 5 & 2 & 9 & 4 & 7 & 8 & 2 & 21 \\
\hline $1986-1990$ & 1 & 6 & 2 & 1 & 10 & 1 & 3 & 3 & 5 & 12 & 2 & 9 & 5 & 6 & 22 \\
\hline 1991-1995 & 2 & 8 & 0 & 1 & 11 & 2 & 0 & 6 & 2 & 10 & 4 & 8 & 6 & 3 & 21 \\
\hline $1996-2000$ & 1 & 2 & 3 & 1 & 7 & 0 & 2 & 3 & 5 & 10 & 1 & 4 & 6 & 6 & 17 \\
\hline 2001-2005 & 2 & 0 & 2 & 1 & 5 & 1 & 0 & 3 & 4 & 8 & 3 & 0 & 5 & 5 & 13 \\
\hline $2006-2010$ & 0 & 2 & 1 & 0 & 3 & 0 & 0 & 1 & 3 & 4 & 0 & 2 & 2 & 3 & 7 \\
\hline Total & 13 & 48 & 11 & 9 & 81 & 6 & 7 & 24 & 23 & 60 & 19 & 55 & 35 & 32 & 141 \\
\hline
\end{tabular}

GRÁFICOS 2 e 3

Formas por natureza do acusado e por faixa de tempo (\%): EM $\times \mathrm{GE}^{13}$
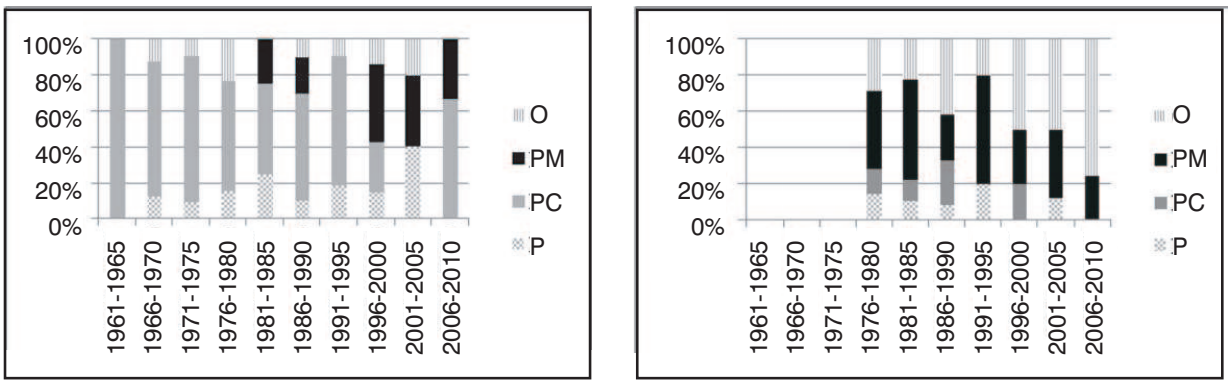

No que diz respeito a EM, há um predomínio nítido de PC (faixa cinza sólida no GRAF. 2); mas, no que tange a GE, predominam PM (faixa preta sólida no GRAF 3) e O (faixa riscada vertical no GRAF. 3), apesar de PM ser levemente mais frequente de forma geral. Há, portanto, indícios da associação EM-PC, como previsto na hipótese levantada, mas a associação GE-PM não seria tão evidente. Deve-se, no entanto, salientar que os resultados da análise por nomeação foram obtidos por amostragem: um texto por ano por veículo de mídia impressa, resultando, após aplicação dos critérios de análise, em um conjunto de 116 textos ex- 
traídos de um corpus de 6272 ( $\pm 2 \%$ ). Em função dessa limitada quantidade da amostra, um caso específico levou a uma alta frequência de $\mathrm{O}$ em GE: trata-se do caso do ex-deputado federal do Acre H.P. a cujo texto se atribuiu aqui o rótulo O, pelo fato de o acusado não aparecer identificado nos textos analisados como militar, apesar de ser coronel reformado da Polícia Militar. Se se atribuísse a rótulo PM (levando em consideração o critério de conhecimento partilhado) para esse caso específico, a associação GE-PM ficaria bastante consistente, levando a frequência de PM, no caso de GE, a 60\% no período 1996-2000, 88\% em 2001-2005 e 75\% em 2006-2010. Essa modificação não tem impacto relevante em EM.

Os resultados aqui encontrados sobre a natureza do acusado de cometer execução (que levam em conta dados referentes a várias regiões do Brasil) são confirmados pelos apurados por Rose (2005, p. 297-298) especificamente para Rio de Janeiro e São Paulo, em que as execuções cometidas pela PM se tornaram expressivamente superiores às pela $\mathrm{PC}$ a partir da década de 80 , padrões igualmente confirmados por Barcelos (1999, p. 126-133), especificamente para São Paulo, e Alves (2003, p. 130), especificamente para a Baixada Fluminense.

Vê-se, portanto, que um novo movimento de mudança no léxico ocorre por volta da década de 80: GE, que desde a década de 70, era um neologismo de sentido que indicava genericamente grupos policiais de execução (sem marcar a corporação de seus membros), passa a incorporar no seu significado um sema de associação a PM, tornando-se um novo neologismo de sentido.

O sinal mais evidente de que GE passou a ser percebido como uma forma com sentido mais específico é que paulatinamente passa a ocupar a posição inicial na cadeia de menção: como se viu antes, inicialmente, GE só aparecia em um texto depois de ter sido mencionada a forma EM, mas por volta da década de 80, GE passa a ocorrer seja antes de EM seja sem qualquer menção a EM. Nos 116 textos analisados por amostragem, a primeira ocorrência de GE sem menção a EM se dá no título notícia de 18/09/1984 [FSP, prim. cad., p. 18]: "Coronel da PM nega ter sugerido grupo de extermínio" (itálico nosso), confirmando assim o uso de GE quando se trata de PM.

Os dados apurados indicam um percurso de mudanças que pode ser assim formalizado com base no sistema de traços distintivos de Pottier (1963, p. 11-17): 


\section{QUADRO 1 \\ Percurso diacrônico de EM e GE no corpus}

\begin{tabular}{ccccc}
\hline & -1961 & $1961-1970$ & $1971-1984 ?$ & $1984+$ \\
\hline EM & $\lceil+$ Exército] & $\lceil+\mathrm{PC}\rceil$ & $\lceil+\mathrm{PC}\rceil$ & $\lceil+\mathrm{PC}\rceil$ \\
\hline GE & - & - & $\lceil+\mathrm{P}\rceil$ & $\lceil+\mathrm{PM}\rceil$ \\
\hline
\end{tabular}

Em síntese: por volta de 1961, EM, forma que já existia no português desde pelo menos 1915, expressando genericamente tropas do exército, adquire um sentido novo ("grupo de policiais civis que cometem execução sumária"), sendo, portanto, nesse momento um neologismo de sentido. Por volta de 1971, surge no corpus GE, como um neologismo de sentido que expressava genericamente "grupo de policiais que cometem execução sumária". Por volta de meados da década de 80 , GE adquire um novo sentido ("grupo de policiais militares que cometem execução sumária"), constituindo, assim, um novo neologismo de sentido. Foram três os movimentos de mudança lexical e foram três transformações sociais que esses neologismos refletiram: (a) a constituição do SDE da Guanabara entre 1957 e 1959, considerado o primeiro EM [com reflexo no léxico do corpus a partir de 1961]; (b) a repressão aos grupos de execução que haviam proliferado a partir de 1969 [com reflexo no léxico do corpus a partir de 1971]; e (c) participação progressiva de PMs em grupos de execução a partir de meados da década de 80 [com reflexo no léxico do corpus a partir aproximadamente de 1984].

Embora seja sedutora a formalização do QUADRO 1, ela pode levar a equívocos de interpretação, pois as mudanças de uma fase para a outra incluem zonas de sobreposição, com uma expressão sendo usada com o sentido idêntico ou muito semelhante ao da outra: os traços semânticos apresentados devem ser entendidos como unidades de sentido que prevalecem no uso real das formas e não como unidades de sentido sempre completamente excludentes no uso.

Feita esta ressalva, pode-se apresentar, como excelente prova da tendência de especialização das formas nas associações EM-PC e GE-PM, um texto jornalístico bastante recente (publicado na revista mensal Caros Amigos): Merlino (2012, p. 10-13) usa 17 vezes GE e 6 vezes EM; para GE, todas as 17 referências dizem respeito a PM, e para EM, 2 se referem à Scuderie Le Cocq (fundamentalmente de PCs), 2 à época da ditadura de forma genérica, 1 ao cabo Bruno ${ }^{15}(=\mathrm{PM})$ e 1 simplesmente a PM (é interessante salientar que, nesta ocorrência, que constitui o subtítulo do artigo, fala-se em "novos esquadrões da morte"). 


\subsubsection{Síntese dos resultados}

No início da seção 3.1, colocou-se uma questão em relação ao estudo de caso considerado: o que o percurso histórico das expressões EM e GE revela em relação ao processo de criação e incorporação de neologismos ao léxico de uma língua? Eis a seguir algumas respostas.

Primeiramente, ficou claro que a proposta da teoria das gerações (faixas de 30 a 36 anos) adotada por Matoré não se sustenta como princípio metodológico. As mudanças lexicais relacionadas a EM e GE não ocorreram segundo essas faixas de tempo: entre o primeiro registro de EM no corpus em 1915 (quando seria um neologismo de forma) até a mudança semântica por que passou por volta de 1961 (quando seria um neologismo de sentido) há um espaço de 46 anos; entre essa mudança e o uso de GE como neologismo de sentido em 1971 passaram-se 10 anos; e entre o referido uso de GE e a mudança semântica por que passou por volta de meados da década de 80 transcorreram-se aproximadamente mais 10 anos - não houve, portanto, neste caso específico mudanças seguindo uma distância temporal de 30 a 36 anos entre si. Os resultados obtidos sugerem recortes temporais de, no máximo, 10 anos, para se poder acompanhar mudanças lexicais. É necessário testar se essa extensão máxima seria também relevante para a história de outros itens lexicais ou se cada item teria história muito particular.

Em segundo lugar, foi possível perceber que as mudanças lexicais não foram exatamente "bruscas" como sugeria Matoré: entre a primeira atestação de EM como neologismo de sentido em 1961 e sua difusão em 1967 passaram-se 6 anos sem registro de uso; igual fato ocorreu entre a primeira atestação do neologismo de sentido GE em 1971 e sua difusão a partir de 1977. Além disso, existe uma nítida gradualidade na correlação entre diminuição do uso de EM e aumento no uso de GE. Não deixa de ser interessante notar, porém, que a difusão inicial de EM na faixa 1966-1970 é bem mais intensa do que de GE na faixa de 19791980. Ainda que se defenda uma mudança brusca para EM (pelo significativo de aumento entre 1961-1965 e 1966-1970), igual reivindicação não se pode fazer para GE (pelo modesto aumento entre 1971-1975 e 1976-1981), ou seja, mudanças bruscas não seriam uma situação categórica.

Em terceiro lugar, verificou-se que a incorporação de neologismos na lingua parece seguir rotas especificas. Como um falante é capaz de interpretar um neologismo? Os dados apurados em relação a EM e GE mostraram uma situação interessante: a introdução de GE no discurso se deu apenas após menção prévia a EM no mesmo texto (recurso que viabilizaria ao falante / leitor interpretar 
o neologismo segundo o sentido que seu usuário / autor lhe deu). Só depois de um tempo em circulação como menção posterior a EM é que GE passa a ocorrer como primeira menção e depois como forma única do texto. A ausência de contextualização dos neologismos no discurso em que ocorrem por parte do método de Matoré impedia efetivamente que aspectos importantes da constituição do léxico como este pudessem ser identificados.

Em quarto lugar, os dados parecem sugerir que, como defendia Matoré, a criação de neologismos seria motivada por transformações sociais (embora não apenas). No caso específico de EM e GE, as transformações sociais consistiram em mudanças nas realidades designadas pelas expressões em questão. Tal postulado já era proposto pelos teóricos do método Palavras e Coisas (MERINGER, 1912), que defendiam que, para entender a história das palavras, é necessário entender a história das coisas que elas designam.

Em quinto lugar, pode-se perceber que a formação de neologismos se dá através de uma interação complexa entre motivações sociais (externas) e motivações linguísticas (internas). Assim, por um lado, foi a proliferação grupos de policiais que cometem execução sumária (motivação externa) que motivou a busca de um hiperônimo (caso de GE em sua fase inicial); mas, por outro lado, a necessidade de uma forma permitisse evitar seguidas repetições de um termo no discurso (motivação interna) também motivou a formação do referido hiperônimo. Essa constatação sugere que, mesmo em estudos do léxico, devem-se considerar tanto o encaixamento interno (intralinguístico) quanto o externo (extralinguístico) nos termos de Weinreich, Labov e Herzog (1968). No caso específico dos estudos do léxico, os fatores sociais seriam de duas ordens: as transformações sociais que motivam a formação de um neologismo (aspecto já tratado no estudo de caso aqui apresentado) e a atuação de aspectos relativos ao perfil dos falantes (gênero, idade, classe social, escolaridade, estilo, etc.). No estudo de caso aqui realizado não foi possível tratar destes últimos aspectos porque o corpus (escrito) terá sido produzido fundamentalmente por falantes com características muito semelhantes: como já dito, predominantemente homens, adultos, com escolaridade, de extrato social médio, em estilo formal (como é praxe nos grandes jornais). É possível dizer, no entanto, que, do ponto de vista geográfico, EM como neologismo de sentido apareceu primeiramente no Rio de Janeiro (não apenas por estar lá o SDE como também pelo fato de a primeira ocorrência desse neologismo no corpus ter sido em texto de correspondente no Rio de Janeiro - cf. dado (2)). 


\section{Considerações finais}

A proposta de Matoré para dar conta do léxico de uma língua fundamentava-se em uma percepção da importância dos fatos sociais. Seu método, porém, apresentava muitas lacunas e inconsistências e foi, por isso, duramente criticado. Lamentavelmente, os modelos de análise lexical igualmente estruturais (como era o de Matoré) que se seguiram negligenciaram totalmente o aspecto social e, apesar de seus avanços em termos de adoção de uma visão sistêmica e de desenvolvimento de métodos de formalização das oposições entre itens lexicais (como a conhecida análise sêmica), deixaram uma enorme lacuna no que se refere às mudanças lexicais: como dar conta de mudanças sem considerar-se também as motivações externas?

Em vista disso, retomar o modelo de Matoré é uma estratégia interessante: não se trata obviamente de tentar aplicá-lo tal como havia sido concebido, pois suas falhas, já bastante comentadas na literatura especializada, impedem a produção de resultados consistentes e coerentes. Curiosamente, para fazê-lo progredir é preciso primeiramente sanar o radicalismo de ter abandonado as questões propriamente linguísticas (a que ele chamou de "secundárias"). O exame dos componentes semânticos dos neologismos certamente oferecerá critérios mais coerentes para o estabelecimento dos postulados campos nocionais. É possível, sim, articular critérios internos (semânticos) e externos (sociais) para representar a estrutura do léxico de uma época: assim, por exemplo, no que diz respeito ao período da ditadura no Brasil, é possível elaborar um microcampo como o de violência de Estado (uma palavra-chave nos termos de Matoré) para reunir os diversos neologismos (palavras-testemunho para Matoré) que apareceram na época para nomear as diferentes formas de tortura; esse microcampo estaria vinculado a um macrocampo que reuniria os diferentes microcampos que representam os aspectos da vida social de uma dada época; o vinculo entre os elementos do microcampo seria de ordem interna (partilhamento de traços semânticos), enquanto o vínculo entre os macrocampos seria de ordem externa (baseado na peculiaridade da realidade social de cada época). Assim, um microcampo como o de violência de Estado apareceria vinculado ao macrocampo de uma época como a da ditadura, mas não ao de uma época de paz social.

Além disso, os recortes temporais de Matoré e sua suposição de limites bem definidos para diferentes épocas da história (baseada na teoria das gerações) devem ser substituídos por uma visão mais dinâmica da evolução linguística e social, em que diferentes aspectos do léxico (não só a criação de um neologismo 
mas também sua efetiva difusão em uma época) são invocados para representar mudanças na história social. Uma tal visão dinâmica supõe ainda encaixar o estudo do léxico nos três principais eixos (temporal, social e espacial) que devem ser considerados para uma compreensão mais global das mudanças, tal como defendeu Labov (1982, p. 20) ao propor a articulação entre linguística histórica, sociolinguística e dialetologia. Uma consequência inevitável é a de que um tal modelo de lexicologia sócio-histórica supõe uma prática mais baseada em estudos aprofundados de casos específicos com o objetivo, a longo prazo, de associação entre eles com base em dados sócio-históricos do que análises descontextualizadas de grandes listas de neologismos.

\section{Notas}

${ }^{1}$ Nesta seção, em nome da brevidade, indica-se apenas a página em que a ideia apresentada se encontra em Matoré (1973). As citações aparecem sempre em tradução nossa. ${ }^{2}$ Matoré (1973, p. 14) assinala, aliás, que terá sido Michel Bréal, em seu Essai de Sémantique (1897), o primeiro a sublinhar a importância do fator social nas evoluções semânticas e lembra ainda que Meillet, em seu Linguistique Historique et Linguistique General (de 1926), considerava que, entre as três causas da mudança semântica que arrola (causas propriamente linguísticas, mudança nas coisas que são expressas pela palavras e ação da divisão dos homens em classes distintas), a última, de fundo social, seria a mais importante.

3 “(...) a concepção, tão difundida quanto errada, segundo a qual a obra dos escritores desempenharia um papel preponderante na evolução da língua. Na realidade, os escritores geralmente não fazem mais que utilizar o léxico de seu tempo e de seu meio [social]. (...) Mesmo quando o escritor está na vanguarda das forças revolucionárias da linguagem, ele não se aventura senão movido pela massa de escritores e de usuários de seu tempo." (MATORÉ, 1973, p. 10).

${ }^{4}$ Uma experiência interessante de estudo de campo lexical na perspectiva de Coseriu no domínio da língua portuguesa é o estudo do campo lexical da "determinação substantiva de simpatia humana e social" entre 1850-1900 realizada por Vilela (1980), a partir de corpus de jornais, revistas e ensaios portugueses: foram considerados os lexemas altruísmo, caridade, confraternidade, filantropia, fraternidade (com duas acepções), humanidade, humanismo, humanitarismo, sociabilidade, solidariedade, desumanidade, egoísmo e insociabilidade. Vilela (1980, p. 216) considera que a faixa de 50 anos é "tempo suficiente e necessário para que a reestruturação [do micro-sistema 
lexical] se opere e se firme".

${ }^{5}$ As siglas EM e GE serão utilizadas aqui para fazer referência tanto à palavra (uma lexia complexa) quanto ao fato da realidade que designam. As expressões esquadrão da morte e grupo de extermínio são consideradas aqui como itens lexicais ou, na terminologia de Alves (1990, p. 50-55), uma composição sintagmática.

${ }^{6}$ É interessante assinalar que a expressão EM já era usada em outro domínio linguístico antes desta data, como se vê na seguinte passagem de jornal espanhol de 1908: "Los guardias nuevos. Desde ayer prestan servicio por parejas los guardias del Cuerpo de Seguridad de Caballería recientemente nombrados. La gente los ha bautizado ya con el nombre de 'Escuadrón de la muerte'."' (ABC, Madrid, 18/06/1908, p. 7, excerto, itálico nosso).

${ }^{7}$ Rose (2005, p. 233) afirma que o SDE teria sido criado por sugestão do policial civil Cecil de Macedo Borer a Kruel em 1957 (ano em que Kruel teria passado a ocupar o cargo de Chefe de Polícia do Departamento Federal de Segurança Pública). Ventura (1994, p. 34-35) afirma que a criação teria ocorrido em 1958.

${ }^{8}$ Considerando que a correção em relação aos fatos históricos em questão é relevante para a presente discussão, fez-se então uma busca na base do jornal Última Hora $(=\mathrm{UH})$ : apurou-se que a primeira ocorrência da expressão EM nesse jornal aparece em 1959 (UH, 09/03/1959, p. 8). É relevante salientar que nessa notícia, que se refere ao assassinato de um criminoso em 06/03/1959, sugere-se de certa forma que a expressão EM já era conhecida na época: "Tudo leva a crer que o perigoso bandoleiro 'Diabo Louro' (...) teria sido eliminado pelos famosos 'esquadrões de morte' da Polícia carioca." (itálico nosso).

${ }^{9}$ Antes desta ocorrência, EM tinha aparecido também no ESP em 16/11/1967 (p. 11), referindo-se a um filme brasileiro: "Perpetuo contra o Esquadrão da Morte, de Miguel Borges, fot. de Constantino Tkaczenko, com Sonia Dutra, Milton Morais e Waldir Onofre" (negrito do original).

${ }^{10}$ Fez-se busca de GE também no já referido Última Hora: a primeira ocorrência data de 1961 (UH, 20/05/1961, p. 6), mas refere-se à ação de nazistas na 2a Guerra Mundial. Na notícia, com título "Grupo de Extermínio", consta ao final: "Êsses chefes nazistas eram: General da SS. A. M., Chefe de Polícia na Iugoslávia; Coronel das SS. H. H., chefe do Grupo Móvel de Extermínio, e Dr. F. comandante de todos os grupos de extermínio da Iugoslávia." (itálico nosso). A primeira ocorrência de GE com o sentido "grupo de policiais que cometem execução sumária" nesse periódico aparece apenas 22 anos depois: "O traficante, contudo, que é ligado aos grupos de extermínio na Baixada Fluminense, fez acusações contra o PM P. H., do $9^{\circ}$ BPM, e o ex-PM e matador profissional Q." (UH, 28/01/1983, p. 9, itálico nosso).

${ }^{11}$ Não se consideraram os dados de 2011 e 2012, porque não formariam faixa de 5 anos. ${ }^{12}$ Como caso emblemático de exibicionismo dos membros dos grupos de execução, pode-se citar o do policial civil Mariel Mariscot, cuja circulação em diversos círculos sociais e na mídia era notória (MENDONÇA \& DAEMON, 2011, p. 5-6). 
${ }^{13}$ Embora a primeira ocorrência de GE em VJ seja na faixa de 1971-1975 (cf. dado (7)), não há registro respectivo no GRAF. 3 (de GE), porque nessa ocorrência não há indicação da natureza do acusado.

${ }^{14} \mathrm{Se}$ se levasse em conta aqui o dado de GE proveniente do UH, esta fase estaria preenchida com o valor [+Exército], pois, como já mencionado, GE era utilizado para nomear as ações de grupos especiais do exército alemão na $2^{a}$ Guerra: esses grupos, que originariamente estavam vinculados à SS (= Schutzstaffel ["Esquadrão de Proteção"]), eram chamados em alemão de Einsatzgruppen ("Grupos de Operação") e teriam entrado em operação por volta da Anexação da Áustria em março de 1938.

${ }^{15}$ Trata-se de militar cuja prisão ocorreu em 1983 (justamente na época em que os termos EM e GE iriam inverter sua predominância em termos de frequência de uso: cf. tabela 1): quiçá pode ter sido justamente esse caso, com sua grande repercussão na mídia, o que catalizou a associação entre GE e PM.

\section{Referências}

ALVES, I. M. Neologismo: criação lexical. São Paulo: Ática,1990.

ALVES, J. C. S. Dos barões ao extermínio: uma história da violência na baixada fluminense. Duque de Caixias, RJ: APPH/CLIO, 2003.

BARCELOS, C. Rota 66. 33. ed. São Paulo: Globo, 1999. [1. ed., 1992]

BICUDO, H. Meu depoimento sobre o esquadrão da morte. São Paulo: Pontifícia Comissão de Justiça e Paz de São Paulo, 1976.

BICUDO, H. Do esquadrão da morte aos justiceiros. São Paulo: Paulinas, 1988.

BLUM, H. Brazil 1961-1964: Introducing the marvelous new world of death squads. In: Killing hope: U.S. military and C.I.A. interventions since World War II. Monroe (ME): Common Courage Press, 2004. p. 163-172.

BRÉAL, M. Essai de Sémantique: essai de signification. Paris: Hachette, 1897.

CARVALHO, N. O que é neologismo. São Paulo: Brasiliense, 1984.

CHEVALIER, J.-C. The analysis of French between the two World Wars (1914-1940). In: FORMIGARI, L.; GAMBARARA, D. (Orgs.). Historical roots of linguistic theories. Amsterdam: John Benjamins Publishing, 1995.

CANDEL, D. Brunot, Ferdinand (1860-1938). In: BROWN, K. (Ed.) Encyclopedia of Language and Linguistics. 2. ed. Boston: Elsevier, 2006.

COSERIU, E. Das Phänomen der Sprache und das Daseinsverständnis des heutigen Menschen. Die Pädagogische Provinz, n. 1-2, p. 11-28, 1967.

CUNHA, L. C. As garras do Brasil na Operação Condor. Brasília, 2012. (Palestra ministrada no Seminário Internacional sobre a Operação Condor, na Câmara dos Deputados, em Brasília, em 05 de julho de 2012). 
GECKELER, H. Semántica estructural y teoría del campo léxico. Madrid: Gredos, 1976. [1. ed. al., 1971]

GORDON, W. T. A history of semantics. Amsterdam/Philadelphia: John Benjamins, 1982. GREIMAS, A. J. La mode en 1830: essai de description du vocabulaire vestimentaire d' après les journaux de mode de l'époque. Paris: Université de Paris-Sorbonne, 1948. (Thèse, Doctorat en Lettres).

GUIRAUD, P. A semântica. 5. ed. Rio de Janeiro: Bertrand, 1989. [1. ed. fr., 1955]

IORDAN, I. Introdução à linguística románica. Lisboa: Calouste Gulbekian, 1973. [1. ed. al., 1962]

JULLEVILLE, L. P. de (dir.) Histoire de la langue française et de la littérature, des origines à nos jours. Paris: Armand Colin, 1905-1968. (13 partes, 23 volumes) / Paris: CNRS, 1985-2000. (3 volumes).

LABOV, W. The study of language in its social context. In: . Sociolinguistic patterns. Philadelphia: University of Philadelphia Press, 1972. p. 183-259.

LABOV, William. Building on empirical foundations. In: LEHMANN, W. P. \& MALKIEL, Y. (Eds.) Perspectives on historical linguistics. Amsterdam/ Philadelphia: John Benjamins, 1982. p. 17-92.

LANGGUTH, A. J. A face oculta do terror. Rio de Janeiro: Civilização Brasileira, 1979. [1. ed. ing., 1978]

MATORÉ, G. La lexicologie sociale. L'Information Littéraire, Paris, n. 2, mar./abr. 1949. MATORÉ, G. Le vocabulaire de la prose littéraire de 1833 à 1845: Théophile Gautier et ses premières oeuvres en prose. Paris: Université de Paris-Sorbonne, 1946. (Thèse, Doctorat en Lettres)

MATORÉ, G. Le vocabulaire et la societé sous Louis-Philippe. Gèneve: Droz, 1951. 369 p. [Rep.: Genève: Sklatine Reprints, 1967]

MATORÉ, G. La méthode en lexicologie: domaine français. Paris: Didier, 1953. [2. ed. ampl., 1973]

MATORÉ, G. Le vocabulaire et la société médiévale. Paris: Presses Universitaires de France, 1985.

MATORÉ, G. Le vocabulaire et la société du XVI siècle. Paris: Presses Universitaires de France, 1988.

MATORÉ, G. \& GREIMAS, A. J. La méthode en lexicologie: a propos de quelques thèses récentes. Romanische Forschungen, Frankfurt am Main, v. 60, n. 3, p. 411-419, 1948.

MATORÉ, G. \& GREIMAS, A. J. La méthode en lexicologie (II). Romanische Forschungen, Frankfurt am Main, v. 62, n. 2-3, p. 208-221, 1950.

MEILLET, A. Linguistique historique et linguistique général. Paris: Champion, 1926. MENDONÇA, K.; DAEMON, F. Do Esquadrão da Morte à Liga da Justiça: uma genealogia da presença dos grupos paramilitares no jornalismo carioca. In: CONGRESSO MUNDIAL DE COMUNICAÇÃO IBERO-AMERICANA, I, São Paulo, 31 julho-04 agosto 2011. Anais... São Paulo: Universidade de São Paulo, 2011. 
MERINGER, R. Zur Aufgabe und zum Namen unserer Zeitschrift. Wörter und Sachen, Heidelberg, v. III, p. 22-56, 1912.

MERLINO, T. Em cada batalhão da PM tem um grupo de extermínio. Caros Amigos, São Paulo, v. 16, n. 186, p. 10-13, set. 2012.

MONTEIRO, J.; BARBOSA, A. Do esquadrão ao mão branca. Rio de Janeiro: Ed. dos Autores, 1980.

POTTIER, B. Recherches sur l'analyse sémantique en linguistique et en traduction mécanique. Nancy: Faculté des Lettres de Nancy, 1963.

REALE JR., M. Virtude e terror. Estado de São Paulo, 3 nov. de 2007, Primeiro Caderno, p. 2.

ROSE, R. S. The unpast: elite violence and social control in Brazil, 1954-2000. Athens: Ohio University Press, 2005.

ROBIN, R. História e linguística. São Paulo: Cultrix, 1977. [1. ed. fr. , 1973]

SPENCER, N. C. W. Linguistic fields, conceptual systems and the Weldbild. Transactions of the Philological Society, v. 60, n. 1, p. 87-106, nov. 1961.

VENTURA, Z. Cidade partida. São Paulo: Companhia das Letras, 1994.

VIDOS, B. E. Manual de linguística românica. Rio de Janeiro: Ed. da UERJ, 1996. [1. ed. hol., 1956]

VILELA, M. O léxico da simpatia: estudos sobre o campo lexical da "determinação substantiva de simpatia humana e social" (1850-1900) e respectivo contexto cultural. Porto: INIC, 1980.

WEINREICH, U.; LABOV, W.; HERZOG, M. Empirical foundations for a theory of language change. In: LEHMANN, W. P. \& MALKIEL, Y. (Eds.) Directions for historical linguistics: a symposium. Austin: University of Texas Press, 1968. 